\title{
MANAGEMENT OF MAGGOT INFLICTED WOUND - AYURVEDIC APPROACH
}

\author{
SATHISH HS ${ }^{1 *}$, RASHMI TM ${ }^{2}$, MALLIKARJUN ADMANI ${ }^{3}$
}

${ }^{1}$ Professor, Department of Shalya Tantra, TMAE's Society Ayurvedic Medical College, Shimoga, Karnataka, India. ${ }^{2}$ Associate Professor, Department of Kayachikitsa, TMAE's Society Ayurvedic Medical College, Shimoga, Karnataka, India. ${ }^{3}$ Associate Professor, Department of Dravyaguna, TMAE's Society Ayurvedic Medical College, Shimoga, Karnataka, India. Email: ayursathishhs@gmail.com

Received: 26 February 2021, Revised and Accepted: 21 March 2021

\section{ABSTRACT}

Unhygienic conditions attract organisms into the pathological lesion and worsen the condition, here is a case wherein the patient with psoriatic skin lesions took treatment from an unqualified person and in addition his unhygienic habit attracted maggots into the foot eating away a major chunk of his normal tissues. The case was diagnosed and treated in lines with fundamental principles of Sushruta. The case is a best example of maggots destructive and repair effect on the tissue, the wound with maggots presence healed faster than with wound without maggots.

Keywords: Vrana, Healing, Maggot

(C) 2021 The Authors. Published by Innovare Academic Sciences Pvt Ltd. This is an open access article under the CC BY license (http://creativecommons.org/ licenses/by/4.0/) DOI: http://dx.doi.org/10.22159/ijas.2021v9i2.41231. Journal homepage: https://innovareacademics.in/journals/index.php/ijas

\section{INTRODUCTION}

Maggots therapy is a very well-known treatment modality for various kinds of illness ranging from non-healing ulcer to various forms of neoplasms [1,2]. The basic reason behind using these biological weapons against these conditions is to remove the dead or necrosed tissue and stimulate healing [3]. Any negligence in the hygiene and care of the wound attracts the maggots which gradually multiplies in number and eats away all the healthy tissue. Here is a such case wherein a patient who was diagnosed with Vicharchika [Psoriasis] took some folklore medications for the skin lesions, the details of which are not clear. On the day of his visit to our hospital, he had infected ulcer on both dorsum of the foot and numerous maggots were seen in the right foot wound. The presence of maggots in the wound resulted in extreme swelling [tissue reaction born out of scavenging activity of maggots] and intolerable pain with bleeding, the description of the same matches invasion of Krimi in the wound as cited by Sushruta in his treatise [4]. This case was treated by abiding to the fundamental principles of wound management as laid down by the Sushruta, the legendary Indian surgeon.

\section{CASE REPORT AND DISCUSSION}

A 54-year-old male was suffering from Vicharchika for 8 years the lesions were mainly situated in both the legs, the symptoms got aggravated for 2 months for which he took some folklore medications [medications details are unclear], he reports to had applied some paste of herbs and bandaged the skin lesions, which he did not open for 1 week as directed by his folklore practitioner. On the day of first visit to our hospital, he presented with severe foul smelling ulcer on dorsum of both foot with high scores of pain, fever, and itching sensation. The bandages were removed to assess the wound and numerous maggots were found inside the ulcer in the dorsum of the right foot while the left foot wound was covered with thick pad of slough with no maggots.

Primary examination revealed that the patient was moderately build with ill nourishment and the clinical vital data such as temperature, pulse, blood pressure, oxygen saturation, and respiration rate were within the normal limits. The blood reports showed raised ESR, WBC and the rest of the hematological factors were within normal limits.
The patient consent was taken for publication of his data in a scientific journal.

\section{Local examination findings}

Ulcers in each foot

Local examination findings are presented in Figs. 1 and 2, and also in Table 1.

\section{Diagnosis and treatment plan}

The condition is diagnosed as Dushtavrana and its management was planned as per the textual guidelines. The preliminary task was to complete remove the maggots from the wound and give wound lavage by medicated Kashayas. To extract the maggots, eucalyptus oil [5] and an application of paste prepared out of leaves of Nimba [Azadirachta indica], sesame seeds and honey was chosen. Decoction of Nimba [Azadirachta indica] was prepared and used for wound lavage. Prophylactic antibiotics were administered for 3 days to prevent systemic infection. On the $1^{\text {st }}$ day, around 600 maggots were extracted and eucalyptus oil soaked plugs and Kalka [paste] of Nimba, sesame seeds and honey was applied, and wound was dressed. On the same day after $5 \mathrm{~h}$ of primary dressing, bandage was reopened and around 100 maggots were extracted, the follow-up dressing was made. During the consecutive daily dressings, no maggots were found and the patient was administered with medications to nullify the inflammatory phase and to alleviate the aggravated doshas. In the consecutive day, dressing's number of maggots was drastically reduced, and on the $3^{\text {rd }}$ day, no maggots were observed in the wound with drastic reduction of the foul odor. The wound on the left foot had a thick pad of slough which was surgically debrided followed by application of Nimba taila mixed with Yavakshara for the autolytic debridement of the unhealthy tissues. Agni [Digestive fire], Vata, and pitta dosha were given prime in formulating treatment plan, on the day of the admission due to the vitiated doshas, agni was drastically reduced, to enhance the agni and also to detoxify the body, Gomutra haritaki was chosen. Shodhana [Detoxification] is the prime modality to be adopted in any case of Dushtavrana as per Sushruta's guidelines to check the progression of the pathological event. Tikta dominant kashaya - Pancha tikta kashaya was preferred for correct the doshic imbalance and improves the metabolism thereby enhancing the repair process. The medications chart was altered depending on the periodic doshic assessment [Table 4]. 


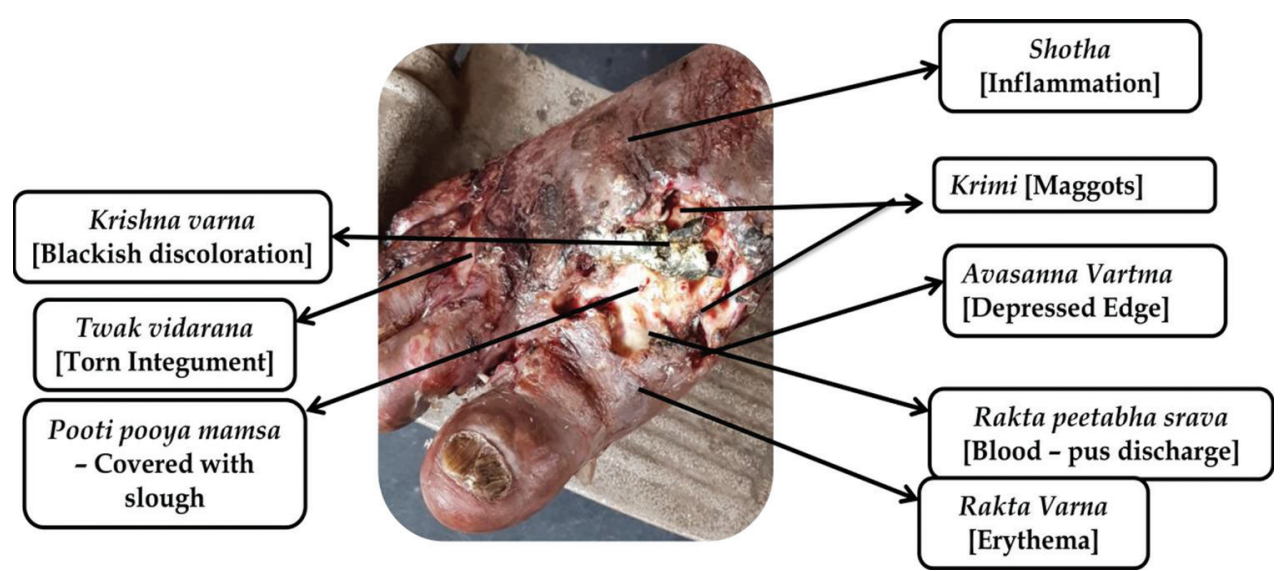

Fig. 1: Examination of the right leg wound

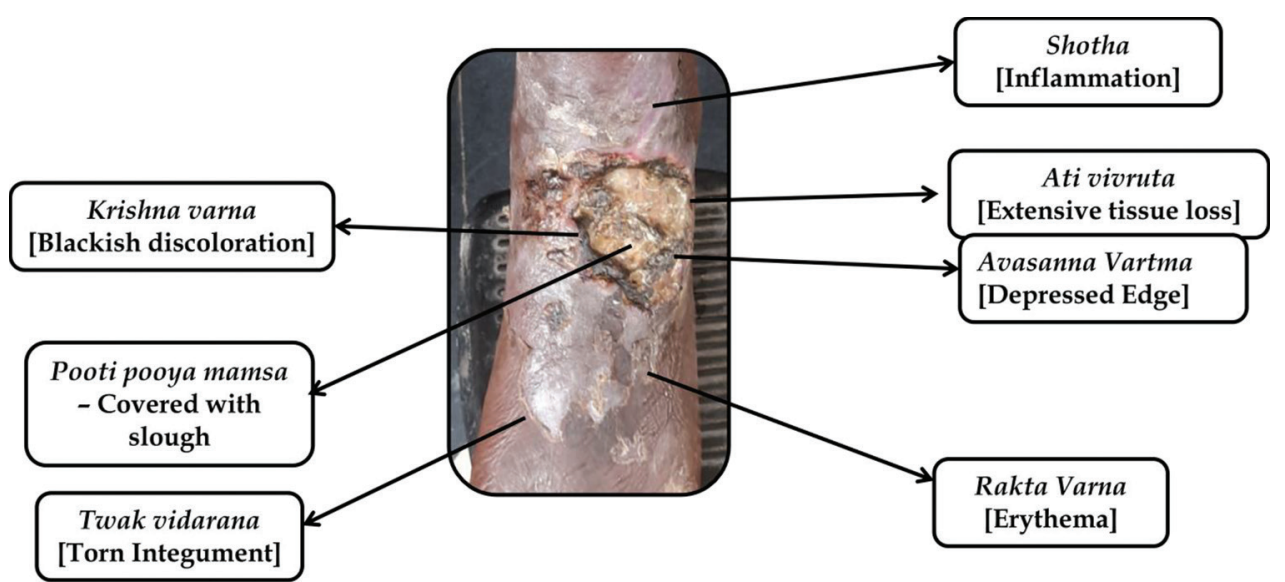

Fig. 2: Examination of the left leg wound

Table 1: Details the local wound examination findings

\begin{tabular}{|c|c|c|}
\hline Wound factors & Right leg ulcer & Left leg ulcer \\
\hline Site & $\begin{array}{l}\text { Dorsum of the foot } \\
\text { in between the } \\
\text { interdigital space of } \\
\text { first and second toe }\end{array}$ & $\begin{array}{l}\text { Dorsum of the foot } \\
\text { just lateral to lateral } \\
\text { malleolus }\end{array}$ \\
\hline Size & - & - \\
\hline Shape & Irregular & Circular \\
\hline Edge & $\begin{array}{l}\text { Edematous and } \\
\text { sloping }\end{array}$ & $\begin{array}{l}\text { Edematous and } \\
\text { sloping }\end{array}$ \\
\hline Margin & Irregular & Regular \\
\hline Floor & $\begin{array}{l}\text { Slough with } \\
\text { numerous maggots }\end{array}$ & Covered with slough \\
\hline Discharge & $\begin{array}{l}\text { Purulent with } \\
\text { bloody discharge }\end{array}$ & Pus discharge \\
\hline Surrounding skin & $\begin{array}{l}\text { Edematous with } \\
\text { psoriatic skin lesions } \\
\text { all over the foot } \\
\text { extending up to knee }\end{array}$ & $\begin{array}{l}\text { Edematous with } \\
\text { psoriatic skin lesions } \\
\text { all over the foot } \\
\text { extending up to knee }\end{array}$ \\
\hline Base & Mobile & Mobile \\
\hline Temperature & Raised & Raised \\
\hline Tenderness & Present & Present \\
\hline Lymphadenopathy & No & No \\
\hline $\begin{array}{l}\text { Signs of vascular } \\
\text { insufficiency }\end{array}$ & No & No \\
\hline
\end{tabular}

The right leg wound responded very well to the medications while the wound on the left foot was showing unhurried response. In the left foot, no maggots were seen from the $1^{\text {st }}$ day which was atypical, and the site of the wound was exactly close to the lateral aspect of ankle joint, frequent joint movements might be the one of the reason for the sluggish response in healing in comparison to the other limb. The results of the treatment on the wound are presented in Tables 2 and3. The scores of pain and swelling decreased, and the appetite of the patient improved. The patient had an irregular bowel evacuation before the admission, on medication, he had 2-3 times bowel evacuation which was necessary to remove the toxins from the body.

The reasons for the enhanced healing pattern observed in the right leg wound which was afflicted with maggots might be due to the secretions produced by the maggots contain proteolytic enzymes which has debriding action on the wound [6]. Many research studies have shown that maggots check the microbial load in the wound, thereby stimulating the repair process [7,8]. Maggot therapy involves use of sterile maggots to debride the unhealthy tissue and to freshen the chronic wound, benign and malignant inoperable lesions. This therapy fastens the healing process and removes the pathological tissues, whereas in this case unsterile maggots invaded the tissue due to unhygienic conditions and resulted in tissue damage. Use of sterile maggots as a biological tool to promote healing, to take away necrosed unhealthy tissue in cases intractable, inoperable surgical cases, here in this case maggots invaded the tissue due to unhygienic maintenance of the skin lesions and it had eaten away the most of the healthy tissues in the vicinity and which has to be removed at the earliest to prevent further tissue damage. This case is an example to showcase an affliction of the maggots in a healthy tissue does undue 
Table 2: The patient photos from starting of treatment to changes observed in the right leg wound

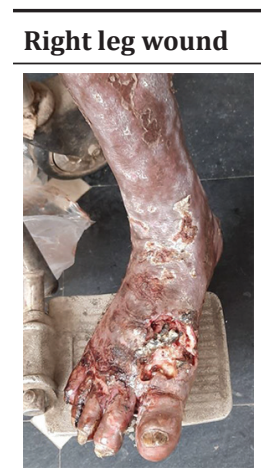

Day 1

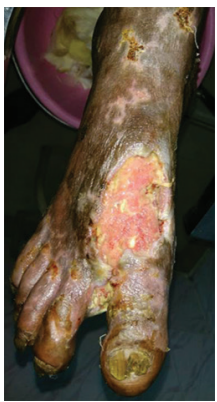

$3^{\text {rd }}$ Day

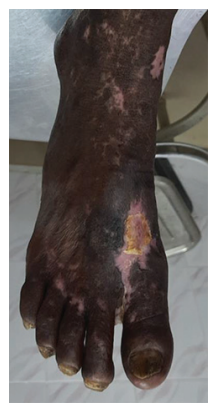

$30^{\text {th }}$ Day

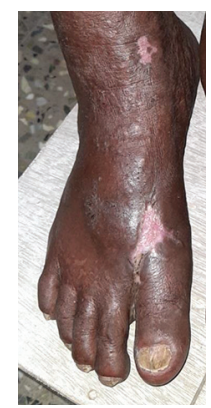

$37^{\text {th }}$ day

harm to the tissue and also it inspires us to use it in the non-healing, unresponsive ulcer, and other surgical cases wherein surgical debridement of the unhealthy tissue is warranted in patients who are unfit for surgical procedure $[9,10]$.

Nimba taila was chosen in this study for the topical application as it possess antimicrobial [11,12], anti-inflammatory, and wound
Table 3: The patient photos from starting of treatment to changes observed in the left leg wound

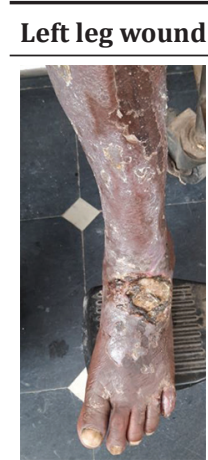

$1^{\text {st }}$ Day

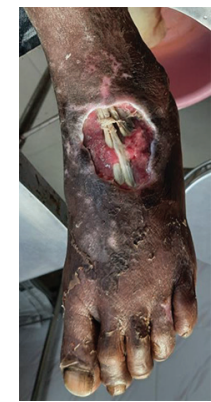

$3^{\text {rd }}$ day

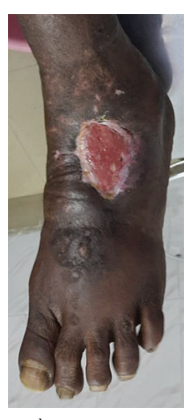

$30^{\text {th }}$ Day

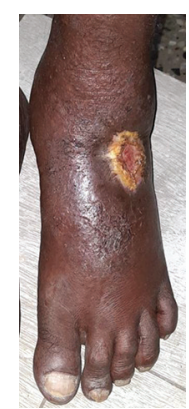

$39^{\text {th }}$ Day

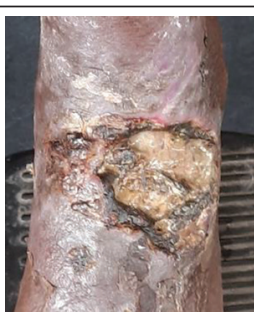

Wound in closet

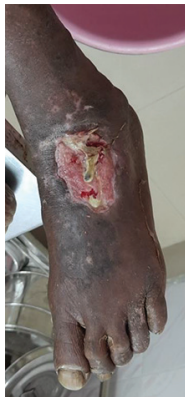

$20^{\text {th }}$ day

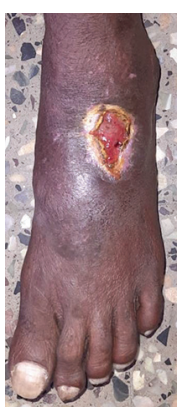

$35^{\text {Th }}$ Day healing properties [13]. Nimba [Azadirachta indica] has proven record of checking the micro- and macro-organism growth inside the wound bed, especially in this case, maggots were the inhabitants [14-16]

The oral medications prescribed during the course of the treatment were Gomutra Haritaki, Panchatikta Kashaya, and Triphala Guggulu [17]. 
Table 4: The drug administered with the posology

\begin{tabular}{lll}
\hline S. No. & Medication & Dose with Anupana \\
\hline 1. & Gomutra Haritaki & $\begin{array}{l}\text { 2 Tab - TID - After food with } \\
\text { warm water }\end{array}$ \\
2. & Panchatikta Kashaya & $\begin{array}{l}\text { 2 tsp with warm water before } \\
\text { food - twice daily }\end{array}$ \\
3. & Triphala Guggulu & 2 Tab - TID - After food with \\
& & warm water \\
\hline
\end{tabular}

Main focus was stressed on the nourishment of the patient and hygiene of the part. The medications enhanced the metabolic rate of the patient and especially Gomutra Haritaki $[18,19]$ assisted in detoxification of the body. These three-drug combinations have yielded significant clinical outcomes in the past, hence, these drugs were chosen and the results are visible.

\section{CONCLUSION}

The presence of maggots in the wound reveals the seriousness of the disease which requires a proper assessment and management to check the more tissue damage and also enhance tissue healing. Maggots have multifaceted therapeutical beneficial effects on the tissue if used methodically, in this case, maggots attracted to the wound due local unhygienic environment has done a considerable tissue damage and the positive aspect is it triggered the healing mechanism, that is, the reason the wound with maggot healed faster when compared to the wound without maggots.

\section{REFERENCES}

1. Mumcuoglu KY, Ingber A, Gilead L, Stessman J, Friedmann R, Schulman H, et al. Maggot therapy for the treatment of intractable wounds. Int J Dermatol 1999;38:623-7.

2. Pechter EA, Sherman RA. Maggot therapy: The surgical metamorphosis. Plast Reconstr Surg 1983;72:567-70.

3. Sherman RA, Mumcuoglu KY, Grassberger M, Tantawi TI. Maggot therapy. In: Biotherapy: History, Principles and Practice. Dordrecht:
Springer; 2013. p. 5-29.

4. Bhishagratna KL An English Translation of the Sushruta Samhita Based on Original Sanskrit Text. Vol. 2. Calcutta: S.L. Bhaduri; 1916 p. 305-6.

5. Majid A, Swapna CR, Khan A, Prakash GV, Khan S. Care and management of wound in animals. Livest Line 2019;12:4-7.

6. Chan DC, Fong DH, Leung JY, Patil NG, Leung GK. Maggot debridement therapy in chronic wound care. Hong Kong Med J 2007; 13:3838-6.

7. Nigam Y, Bexfield A, Thomas S, Ratcliffe NA. Maggot therapy: The science and implication for CAM part II-maggots combat infection. Evid Based Complement Altern Med 2006;3:303-8.

8. Sherman RA, Shimoda KJ. Presurgical maggot debridement of soft tissue wounds is associated with decreased rates of postoperative infection. Clin Infect Dis 2004;39:1067-70.

9. Horn KL, Cobb AH, Gates GA. Maggot therapy for subacute mastoiditis. Arch Otolaryngol 1976;102:377-9.

10. Fine A, Alexander H. Maggot therapy: Technique and clinical application. J Bone Joint Surg 1934;16:572-82.

11. SaiRam M, Ilavazhagan G, Sharma SK, Dhanraj SA, Suresh B, Parida MM, et al. Anti-microbial activity of a new vaginal contraceptive NIM-76 from neem oil (Azadirachta indica). J Ethnopharmacol 2000;71:377-82.

12. Jahan T, Begum ZA, Sultana S. Effect of neem oil on some pathogenic bacteria. Bangladesh J Pharmacol 2007;2:71-2.

13. Kumar SA, Kumar SP, Kumar SV. Evaluation of Nimba Taila and Manjistha Churna in non healing ulcer. Int Res J Pharm 2011;2:201-10.

14. Girish K, Shankara BS. Neem - A green treasure. Electron J Biol 2008;4:102-11.

15. Bhowmik D, Chiranjib YJ, Tripathi KK, Kumar KS. Herbal remedies of Azadirachta indica and its medicinal application. J Chem Pharm Res 2010;2:62-72.

16. Nicoletti M, Murugan K. Neem the tree of $21^{\text {st }}$ century. Pharmacologyonline 2013;3:115-21.

17. Tomar R, Kaur G, Sannd R, Singh H, Sarkar B. A review on guggulu formulations used in Ayurveda. Ann Ayurvedic Med 2014;3:96-113.

18. Manani YL, Dei LP, Donga SB, Harisha CR, Shukla VJ. Evaluation of Gomutra Haritaki-An Ayurvedic compound. Invent Rapid Pharm Anal Qual Assur 2016;1:1-4.

19. Anonymous. Part 2: The Ayurvedic Pharmacopoeia of India. $1^{\text {st }}$ ed., Vol. 1. New Delhi: Ministry of Health and Family Welfare, Government of India; 2008. p. 136-9. 